\title{
HUBUNGAN ANTARA PEMANFAATAN MEDIA INTERNET SEBAGAI SUMBER BELAJAR TERHADAP MOTIVASI BELAJAR SISWA KELAS X AKUNTANSI SMK NEGERI 46 JAKARTA
}

\author{
Sintia Arlia* \\ Ati Sumiati*
}

\begin{abstract}
This research was aimed to obtain valid data and facts about the relationship between the use of the internet as a source of learning for class $X$ student motivation Accounting SMK 46 Jakarta. This research was conducted by survey method with correlation approach. This study was conducted in January to February 2015. The study population was all students of SMK 46 Jakarta. Affordable population in this study were students of class $X$ Accounting totaling 71 students. The number of samples used as research is 62 students. The sampling technique used is proportional random technique. Instruments used in the form of a questionnaire study of 20 grains to use the internet as a source of learning and 36 grains for student motivation variables. The results showed that: there is a positive relationship between utilization of the internet as a source of learning on the students motivation Grade 10 Accounting in Vocational High School 46 Jakarta. Thus if the utilization of the internet as a source increases, the learning on the students motivation will also increase.
\end{abstract}

Keywords: utilization of the internet as a source, learning on students motivation.

\section{PENDAHULUAN}

Motivasi penting dalam menetukan seberapa banyak siswa akan belajar dari suatu kegiatan pembelajaran atau seberapa banyak menyerap informasi yang disajikan kepada mereka. Siswa yang termotivasi untuk belajar sesuatu akan menggunakan proses kognitif

\footnotetext{
* Sitia Arlia dan Ati Sumiati. Fakultas Ekonomi Universitas Negeri Jakarta
}

yang lebih tinggi dalam mempelajari materi itu, sehingga siswa itu akan menyerap dan mengendapkan materi itu dengan lebih baik. Motivasi belajar siswa merupakan faktor utama yang menentukan keberhasilan belajarnya. Kadar motivasi ini banyak ditentukan oleh kadar kebermaknaan bahan pelajaran dan kegiatan pembelajaran yang dimiliki oleh siswa yang bersangkutan. 
Di era globalisasi perkembangan ilmu dan teknologi sangat pesat. Oleh karena dalam dunia pendidikan pun tidak terlepas dari perkembangan internet. Dalam dunia pendidikan sering kali muncul masalah yang berhubungan dengan proses pembelajaran yaitu lemahnya proses pembelajaran. Dalam proses pembelajaran, seorang guru memiliki peranan penting demi tercapainya kegiatan pembelajaran di sekolah. Guru menjadi ujung tombak terciptanya proses pembelajaran. Meskipun guru mempunyai kecerdasan tanpa didukung dengan media pembelajaran yang baik maka proses pembelajaran itu akan menjenuhkan dan kurang menarik motivasi belajar siswa. Untuk itu dalam pembelajaran perlu adanya media pembelajaran yaitu internet. Dengan adanya media tersebut setiap siswa mampu memanfaatkan internet sesuai dengan kebutuhan pendidikan.Di samping itu pemanfaatan internet sebagai media pembelajaran sangat mempermudah siswa dalam dalam mengakses sebuah informasi pengetahuan, mengirim tugas-tugas sekolah lewat email, dan sebagainnya.Selain siswa, guru juga dapat mempermudah dalam menyampaikan pembelajaran. Pemanfaatan media internet sangat penting bagi terlaksananya pembelajaran yang baik.

Dalam suatu kasus, salah satu faktornya adalah kondisi lingkungan siswa, dalam sebuah kasus Bupati $\begin{array}{lr}\text { Bangka, Tarmizi } & \text { sangat } \\ \text { menyayangkan banyak sekali } \\ \text { lingkungan sekolah yang masik }\end{array}$ kurang sedap dipandang mata, karna banyak sekali sekolah yang kurang bersih. Dan mengingatkan seluruh pengelola lembaga sekolah mulai dari tingkat kanak-kanak sampai sekolah atas agar tetap menjaga kebersihan lingkungan sekolah. Jadi apabila kondisi sekolah nyaman dan kondusif akan membangkitkan motivasi siswa untuk belajar (Bangka, 14 Maret 2015).

Selain itu ada faktor upaya guru dalam membelajarkan siswa maksud dalam faktor ini yaitu guru menguasai semua kompetensi atau keahlian yang harus dimilikinya. Dalam sebuah artikel TEMPO.CO, Jakarta - Presiden Republik Indonesia Susilo Bambang Yudhoyono kecewa dengan kualitas yang dimiliki oleh para guru di Tanah Air. "Dari 285 ribu guru yang ikut uji kompetensi, ternyata 42,25 persen masih di bawah rata-rata kita," kata SBY sesuai sidang kabinet terbatas di kantor Kementerian Pendidikan dan Kebudayaan, Selasa, 31 Juli 2012. Anggota Dewan Pendidikan Pamekasan, Mohammad Zaini mengatakan "sebagian guru tidak sepenuhnya mampu memberikan contoh yang baik terhadap para muridnya. Padahal kepribadian mereka sangat mendukung bagi terciptanya karakter siswa yang baik dan mampu memberikan dorongan kepada siswa agar termotivasi 
dalam pembelajaran" (Tempo, 16 Maret 2015).

Faktor selanjutnya adalah kemampuan siswa, Berdasarkan penelitian pusat pedesaan dan kawasan, Universitas Gadja Mada $(8 / 12 / 2012)$ menyatakan bahwa anak yang berasal dari keluarga miskin tidak akan mampu mengembangkan diri secara maksimal. Berdasarkan hasil penelitia yang diseponsori oleh beberapa lembaga internasional yang dilaksanakan dengan metode survei didesa ngumpasan, yogyakarta menyatakan bahwa,"masih banyak terdapat anak yang berasal dari keluarga miskin dan mengalami tingkatan inteligensi dan motivasi belajar yang lebih rendah sehingga memiliki peluang yang lebih besar untuk tidak naik kelas, drop out, dan menikah dalam usia dini bandingkan dengan anak yang berasal dari keluarga mapan" (PSPK UGM, 16 Maret 2015).

Kemudian, Wakil Presiden RI, Boediono berkunjung ke SMA Negeri 4 Kota Ternate, Maluku Utara untuk bersilaturahmi dengan siswa-siswi SMA se-Kota Ternate. Dalam acara tersebut, salah seorang siswa mengeluhkan masih minimnya sarana dan prasarana untuk pengembangan diri dan sulitnya jaringan internet di wilayah mereka. "Sekolah kami sudah bekerja dengan Dinas Pendidikan untuk meningkatkan mutu tersebut, namun dalam segi anggaran sangat minim. Untuk itu kami mohon agar Pak Wakil Presiden bisa memberikan bantuan agar fasilitas tersebut dapat tercukupi dan membuat siswa lebih giat dan termotivasi untuk belajar," katanya. Menjawab keluhan siswa, Boediono berjanji akan merealisasikan apa yang diinginkan para siswa agar kualitas pendidikan di Ternate semakin baik (Detik.com, 12 Januari 2015).

Selanjutnya, menurut Kompas.com, kasus penggunaan media pengajaran yang digunakan oleh guru, di SMA Yogyakarta masih cenderung membosankan. Sebagian besar guru mengajar dengan gaya berceramah dan minim memanfaatkan media pembelajaran. Proses pembelajaran yang kurang menarik membuat daya serap siswa pada pelajaran tidak optimal dan kurang termotivasi untuk belajar. "Benda-benda yang ada di kelas saja seperti komputer dan LCD belumbanyak dimanfaatkan untuk alat bantu mengajar, apalagi menyiapkan media pembelajaran dari rumah," tutur Ujang Fahmi, peneliti JP2KY di Yogyakarta (Kompas, 9 Desember 2014).

Selain dari pada kasus-kasus diatas, berdasarkan hasil wawancara praktikan dengan kepala perpustakaan SMKN 46 Jakarta, pemanfaatan media internet sebagai sumber belajar merupakan salah satu faktor yang mempengaruhi motivasi belajar siswa.Dengan kapasitas 40 bandwith/Mbps, penempatan wifi sebagai sumber internet di SMKN 46 Jakarta dibagi menjadi 3 jalur utama. 
Tabel 1.Pemanfaatan Jaringan Wifi/ Internet di SMKN 46 Jakarta

\begin{tabular}{|c|c|c|}
\hline Jalur 1 & Jalur 2 & Jalur 3 \\
\hline $\begin{array}{l}\text { Dengan total jumlah wifi } \\
\text { sebanyak } 5 \text { (lima) pcs. } \\
\text { Pemanfaatannya } \\
\text { digunakan untuk : } \\
\text { 1. Ruang guru } \\
\text { 2. Ruang kajur } \\
\text { 3. Ruang TU } \\
\text { 4. Ruang Kepsek } \\
\text { 5. Ruang Wakasek }\end{array}$ & $\begin{array}{l}\text { Dengan total jumlah wifi } \\
\text { sebanyak } 1 \text { (satu) pcs. } \\
\text { Pemanfaatannya } \\
\text { digunakan untuk : } \\
\text { 1. Ruang Perpustakaan }\end{array}$ & $\begin{array}{l}\text { Dengan total jumlah wifi } \\
\text { sebanyak } 24 \text { (dua puluh } \\
\text { empat)pcs dan di setiap } \\
\text { lantainya terdapat } 8 \text { wifi. } \\
\text { Pemanfataanya } \\
\text { digunakan untuk: } \\
\text { 1. Ruang siswa lantai } 1 \\
\text { 2. Ruang siswa lantai } 2 \\
\text { 3. Ruang siswa lantai } 3\end{array}$ \\
\hline
\end{tabular}

Sumber : Perpustakaan SMKN 46 Jakarta

Dari data yang diperoleh dari perpustakaan SMK N 46 Jakarta pemanfaatan media internet telah digunakan secara maksimal. Sehingga dengan adanya WIFI, baik guru maupun siswa dapat mengakses internet untuk kegiatan belajar mengajar di sekolah dengan mudah dan cepat.

Berdasarkan hal-hal yang telah dikemukakan diatas mengenai faktor-faktor yang mempengaruhi motivasi belajar maka peneliti tertarik untuk mengambil salah satu faktor yang berperan penting dalam memotivasi belajar siswa yaitu meneliti masalah pemanfaatan media internet sebagai sumber belajar. Oleh karena itu, penelitian dengan judul, Pemanfaatan Media Internet Sebagai Sumber Belajar Terhadap Motivasi Belajar Siswa menjadi hal yang menarik untuk diteliti secara lebih mendalam.

\section{Perumusan Masalah}

Berdasarkan pada latar belakang di atas, maka permasalahan yang menjadi fokus penelitian ini adalah
"Apakah terdapat hubungan antara pemanfaatan media internet sebagai sumber belajar terhadap motivasi belajar siswa kelas X Akuntansi SMA N 46 Jakarta?"

\section{KAJIAN TEORETIK Motivasi Belajar}

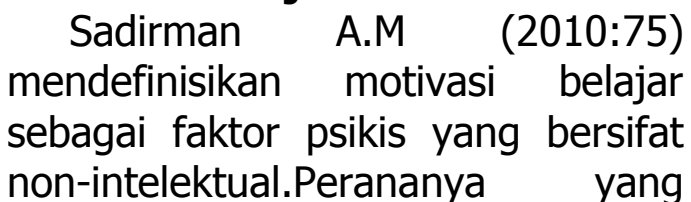
khas dalam hal penumbuhan gairah, merasa senang dan semangat untuk belajar. Siswa yang memiliki motivasi belajar yang kuat, akan mempunyai banyak energi untuk melakukan kegiatan belajar.

Winkel

(2012:180) mendefinisikan motivasi belajar sebagai motivasi yang diterapkan dalam kegiatan belajar mengajar dengan keseluruhan penggerak psikis dalam diri siswa yang menimbulkan kegiatan belajar, menjamin kelangsungan belajar dalam mencapai satu tujuan.

Monk dan Singgih Gunarsa (2009:90) mendefinisikan motivasi 
belajar merupakan segi kejiwaan yang mengalami perkembangan, artinya terpengaruh oleh kondisi fisiologis dan kematangan psikologi siswa.Motivasi belajar diperkuat dengan adanya sikap, emosi, kesadaran, kebiasaan, dan kemauan.

Berdasarkan

beberapa pengertian yang telah dijelaskan di atas, maka dapat disimpulkan bahwa motivasi belajar merupakan sesuatu keadaan yang terdapat pada diri seseorang individu dimana ada suatu dorongan untuk melakukan sesuatu guna mencapai tujuan dalam pembelajaran.

Sebagaimana telah disebutkan di atas bahwa setiap ahli memiliki pandangan yang tak jauh berbeda mengenai definisi motivasi belajar. Terdapat pula pendapat beberapa ahli yang mengemukakan mengenai jenis-jenis dari motivasi belajar.

Oemar Hamalik (2005:162) mengatakan motivasi belajar dibagi menjadi dua jenis, yaitu motivasi intrinsik dan eksrinsik. Motivasi intrinsik adalah motivasi yang bersifat rill seperti, dorongan untuk belajar berasal dari dalam diri, adanya keinginan untuk belajar suatu keterampilan tertentu, ingin mencapai keberhasilan dalam belajar, dan ingin meraih cita-cita dimasa depan.Motivasi ekstrinsik adalah motivasi yang disebabkan oleh faktor-faktor dari luar situasi belajar, seperti tingkat hadiah, lingkungan belajar, medali, angka ijazah dan persaingan.
Iskandar (2012:181) bahwa motivasi belajar bisa timbul karena faktor intrinsik atau faktor dari dalam diri manusia yang disebabkan oleh dorongan dari dalam diri, keinginan untuk berhasil, kebutuhan belajar dalam mencapai tujuan, harapan, dan cita-cita. Faktor ekstrinsik juga mempengaruhi dalam motivasi belajar, berupa adanya penghargaan, lingkungan belajar yang menyenangkan, dan kegiatan belajar yang menarik.

Monks, Knoers, Siti Rahayu (2009:90) bahwa motivasi belajar seseorang dapat bersumber dari dalam diri sendiri yang dikenal sebagai motivasi intrinsik dan dari luar seseorang yang dikenal sebagai motivai ekstrinsik. Dalam hal ini, motivasi intrinsik terkait dengan dorongan dari dalam diri siswa, adanya cita-cita siswa, dorongan dari dalam diri untuk belajar, dan kemampuan siswa untuk berhasil.Sedangkan motivasi ekstrinsik adalah dorongan terhadap perilaku seseorang yang ada di luar perbuatan yang dilakukannya, kondisi lingkungan siswa, pemberian penghargaan berupa hadiah, kritikan, dan hukuman.

Hamzah B.Uno (2006:9) berpendapat motivasi belajar timbul karena faktor intrinsik, berupa hasrat dan keinginan berhasil, dorongan kebutuhan belajar, dan adanya harapan akan cita-cita masa depan. Sedangkan faktor ekstrinsiknya adalah adanya penghargaan, lingkungan belajar 
yang kondusif, dan kegiatan belajar yang menarik.

Berdasarkan

pemahaman mengenai jenis-jenis motivasi belajar yang telah disebutkan di atas, maka dapat disimpulkan bahwa yang menjadi faktor dalam motivasi belajaradalah motivasi belajar intrinsikdan ekstrinsik yang dapat membangkitkan seseorang atau suatu kelompok untuk bertindak, terdorong untuk mencapai tujuan tertentu, dan tetap tertarik dalam kegiatan tertentu.Jenis-jenis yang menjadi faktor dari motivasi belajar siswa diklasifikasikan sebagai berikut:

a. Motivasi Belajar Intrinsik dengan ciri : (1) Adanya dorongan dan kebutuhan dalam belajar, (2) Adanya hasrat dan keinginan berhasil, (3) Adanya keinginan untuk mencapai tujuan yang terkandung di dalam perbuatan belajar itu sendiri, (4) Adanya dorongan dari dalam diri yang berkaitan dengan aktivitas belajar, (5) Adanya harapan dan cita-cita dimasa depan.

b. Motivasi Belajar Ekstrinsik dengan ciri : (1) Adanya penghargaan dalam belajar, (2) Ingin mendapatkan pujian, (3) Adanya sesuatu yang mendesak siswa dalam aktivitas belajar, (4) Adanya kegiatan yang menarik dalam belajar, (5) Adanya lingkungan belajar yang kondusif, sehingga memungkinkan seoarang siswa dapat belajat dengan baik.

\section{Pemanfaatan Media Internet Sebagai Sumber Belajar}

Bambang Warsita (2008:37) pemanfaatan media pembelajaran ialah penggunaan secara sistematis sari sumber belajar. Proses pemanfaatan media merupakan proses pengambilan keputusan berdasarkan pada spesifikasi desain pembelajaran. Prinsip-prinsip pemanfaatan media juga dikaitkan dengan karakteristik peserta didik.

Miarso (2010:79) mengatakan bahwa pemanfaatan media termasuk dalam fungsi pembelajaran (kawasan teknologi pendidikan) mencakup hal-hal seperti : penggunaan sumber belajar, pemberian tugas, memilih materi pelajaran, penyampaian informasi, dorongan minat belajar, dan monitor kegiatan belajar. Fungsi pemanfaatan dalam pengembangan media pembelajaran adalah mengusahakan agar pembelajar dapat berinteraksi dengan sumber atau komponen instruksional.

Hamalik (2011:15) bahwa pemakaian/ pemanfaatan media pembelajaran dalam proses belajar mengajar dapat membangkitkan keinginan dan minat yang baru, membangkitkan motivasi dan rangsangan kegiatan belajar, dan bahkan membawa pengaruhpengaruh psikologis terhadap siswa.

Nana Sudjana (2006:152) pemanfaatan media pembelajaran menjadi enam kategori, yaitu: (a) Pemanfaatan media mempunyai fungsi sebagai alat bantu untuk mewujudkan situasi belajar 
mengajar yang efektif (b) Pemanfaatan media pembelajaran merupakan bagian yang integral dari keseluruhan situasi mengajar (c) Media pembelajaran dalam pengajaran, integral dengan tujuan dari isi pelajaran (d) Pemanfaatan media pembelajaran bukan sematamata sebagai alat hiburan (e) Pemanfaatan media lebih diutamakan untuk mempercepat proses belajar mengajar dan membantu siswa dalam menangkap pemgertian yang diberikan guru ( $f$ ) Pemanfaatan media pembelajaran diutamakan untuk mempertinggi mutu belajar mengajar.

Berdasarkan

pemahaman pemanfaatan media belajar sebagai sumber belajar yang telah disebutkan di atas, maka dapat disimpulkan bahwa pemanfaatan media belajar sebagai sumber belajar adalah aktivitas menggunakan proses, cara, dan perbuatan memanfaatkan media/ sumber untuk kegiatan belajar mengajar.

Kitao (2012:8.6) terdapat beberapa manfaat dari media internet yang digunakan sebagai sarana pembelajaran, yaitu : (a) Memiliki sumber informasi yang banyak (b) Terdapat fasilitas e-mail, web, chatting, dan mailing list sebagai interaksi antar individu (c) Materi pembelajaran yang dimasukan dalam internet dirancang secara multimedia (d) Penggunaan yang meluas (e) Akses yang cepat.

Oetomo (2007:12) media internet menawarkan berbagai manfaat dalam bidang pendidikan diantaranya : (a) Kemampuan dan kecepatan akses komunikasi (b) Penggunaan peralatan berbasis multimedia (c) Ketersediaan informasi yang up to date (d) Adanya fasilitas News Group, web pendidikan, dan e-mail.

Niken Ariani dan Dany Haryanto (2010:178) dalam pelaksanaan pembelajaran di kelas terdapat beberapa manfaat dalam penggunaan media internet, yaitu : (a) Sebagai penguasaan teknologi dan akses komunikasi (b) Sebagai perangkat fasilitator atau sumber belajar dari seluruh mata pelajaran yang ada (c) Sebagai pengintegrasian semua fasilitas yang tersedia dalam internet untuk pelajaran seperti e-mail,dan situs web (d) Penggunaan aplikasi khusus seperti simulasi soal ujian, visualisasi animasi, film dan multimedia.

Berdasarkan pemahaman pemanfaatan media internet sebagai sumber belajar yang telah disebutkan di atas, maka dapat disimpulkan bahwa faktor dari pemanfaatan media internet sebagai sumber belajarialah sumber informasi yang up to date, adanya fasilitas interaksi antarindividu,kemampuan dan kecepatan akses komunikasi, materi pembelajaran yang dirancang secara multimedia, dan penggunaan yang meluas yang tersebar di seluruh dunia. 


\section{METODOLOGI PENELITIAN}

Tujuan penelitian ini adalah untuk mendapatkan pengetahuan berdasarkan data dan fakta yang valid serta dapat dipercaya untuk mengetahui hubungan antara pemanfaatan media internet sebagai sumber belajar terhadap motivasi belajar siswa kelas $X$ akuntansi SMKN 46 Jakarta.

Metode yang digunakan dalam penelitian ini adalah metode survey dengan pendekatan korelasional.

Populasi dalam penelitian ini adalah seluruh siswa di SMKN 46 Jakarta Tahun Ajaran 2014/2015. Adapun populasi terjangkaunya yaitu siswa kelas $X$ Jurusan Akuntansi yang dengan jumlah siswa sebanyak 71 orang yang terbagi dalam 2 kelas. Kemudian berdasarkan tabel Isaac dan Michael dengan taraf kesalahan 5\%, maka jumlah sampel sebanyak 62 siswa.

Sebelum dilakukan pengujian hipotesis, terlebih dahulu dilakukan pengujian persyaratan analisis, meliputi Uji Normalitas dan Uji Linearitas Regresi.

Teknik yang digunakan untuk melakukan pengujian normalitas data adalah Uji Liliefors. Data yang terkumpul kemudian dianalisis dengan regresi dan korelasi.

\section{HASIL DAN PEMBAHASAN}

Berikut adalah distribusi data hasil penelitian.

Tabel 2.Rangkuman Deskripsi Data

\begin{tabular}{|l|l|l|}
\hline $\begin{array}{c}\text { Nilai Tendensi } \\
\text { Sentral }\end{array}$ & $\begin{array}{c}\text { Pemanfaatan Media } \\
\text { Internet Sebagai } \\
\text { Sumber Belajar (X) }\end{array}$ & \multicolumn{1}{|c|}{$\begin{array}{c}\text { Motivasi Belajar } \\
\text { Siswa (Y) }\end{array}$} \\
\hline $\mathrm{N}$ & 62 & 62 \\
\hline Mean & 87,61 & 160,08 \\
\hline Std. Deviasi & 4,37 & 7,35 \\
\hline Varians & 22,37 & 53,94 \\
\hline
\end{tabular}

\section{Uji Persyaratan Analisis}

Uji Normalitas

Pengujian normalitas

digunakan adalah Uji Liliefors. Hasil
Uji Normalitas terdapat pada tabel 3 berikut:

Tabel 3.Rangkuman Hasil Uji Normalitas

\begin{tabular}{|l|l|l|l|l|}
\hline $\begin{array}{l}\text { Galat } \\
\text { Taksiran } \\
\text { Regresi }\end{array}$ & N & Lhitung & $\begin{array}{l}\text { Ltabel } \\
\alpha=5 \%\end{array}$ & Keterangan \\
\hline Y atas X & 62 & 0,051 & 0,113 & Normal \\
\hline
\end{tabular}


Uji Linearitas Regresi

Bentuk persamaan

dibuktikan dengan hasil

penghitungan. $F_{\text {hitung }}=1,67$;

sedangkan $\mathrm{F}_{\text {tabel }}=1,90$.

\section{Pengujian Hipotesis}

Tabel 4.ANAVA Uji Keberartian dan Kelinearan Regresi

\begin{tabular}{|c|c|c|c|c|c|c|}
\hline $\begin{array}{l}\text { Sumber } \\
\text { Varians } \\
\end{array}$ & $\mathbf{d k}$ & $\begin{array}{c}\text { Jumlah } \\
\text { Kuadrat (JK) } \\
\end{array}$ & $\begin{array}{r}\text { Rata-rata Jumlah } \\
\text { Kuadrat (RJK) }\end{array}$ & $\overline{F_{\text {hitung }}}$ & $\mathbf{F}_{\text {tabel }}$ & Keterangan \\
\hline Total & 62 & 1592091.00 & & & & \\
\hline Regresi (a) & 1 & 1588800.40 & & & & \\
\hline Regresi (b/a) & 1 & 1170.60 & 1170.60 & \multirow{2}{*}{33.13} & \multirow{2}{*}{4.00} & $\begin{array}{c}\text { Ho harus } \\
\text { ditolak }\end{array}$ \\
\hline Residu (S) & 60 & 2119.99 & 35.33 & & & Regresi berarti \\
\hline Tuna Cocok & 19 & 924.66 & 48.67 & \multirow{2}{*}{1.669} & \multirow{2}{*}{1.90} & $\begin{array}{c}\text { Ho tidak harus } \\
\text { ditolak }\end{array}$ \\
\hline Galat Kekeliruan & 41 & 1195.33 & 29.15 & & & Regresi linier \\
\hline
\end{tabular}

Berdasarkan tabel di atas, dapat dinyatakan bahwa persamaan regresi tersebut adalah signifikan dan linear. Selanjutnya, tingkat hubungan antarvariabel dihitung
Hasil analisis data menginformasikan bahwa persamaan regresi pasangan variabel ini adalah $\hat{Y}=78,94+$ $0,926 X$. Hasil pengujian signifikansi dan linearitas persamaan regresi disajikan pada tabel 4 .

Tabel 5.Pengujian Signifikasi Koefisien Korelasi

\begin{tabular}{|l|l|l|l|l|}
\hline $\begin{array}{l}\text { Persamaan } \\
\text { Regresi }\end{array}$ & $\begin{array}{l}\text { Koefisien } \\
\text { Korelasi }\end{array}$ & $\begin{array}{l}\text { Koefisien } \\
\text { Determinasi }\end{array}$ & thitung & $t_{\text {tabel }}$ \\
\hline $\begin{array}{l}\hat{Y}=78,94+ \\
0,926 \mathrm{X}\end{array}$ & 0,596 & $35,57 \%$ & 5,76 & 1,67 \\
\hline
\end{tabular}

Berdasarkan hasil pengujian signifikansi seperti yang terlihat pada tabel di atas, diketahui bahwa koefisien korelasi antara melalui korelasi Product Moment, kemudian koefisien determinasi. Hasil pengujian disajikan pada tabel 5. pemanfaatan media internet sebagai sumber belajar $(X)$ dengan motivasi belajar siswa ( $Y$ ) termasuk pada kategori sedang. Selain itu, 
berdasarkan uji $\mathrm{t}$ yang telah dilakukan, diketahui pula bahwa terdapat hubungan yang positif antarkedua variabel. Dengan kata lain, semakin tinggi pemanfaatan media internet sebagai sumber belajar, maka motivasi berlajar siswa akan semakin tinggi pula.

Koefisien determinasi sebesar 0,3557 menunjukkan bahwa sebesar $35,57 \%$ variabel yang terdapat pada motivasi belajar siswa ditentukan oleh variabel pemanfaatan media internet sebagai sumber belajar dengan persamaan regresi $\hat{Y}=$ $78,94+0,926 X$.

\section{KESIMPULAN, IMPLIKASI, DAN SARAN \\ Kesimpulan}

Berdasarkan hasil analisis dan penghitungan, maka dapat disimpulkan bahwa terdapat hubungan yang positif antara pemanfaatan media internet sebagai sumber belajar terhadap motivasi belajar siswa. Besaran pengaruh pemanfaatan media internet sebagai sumber belajar terhadap motivasi belajar siswa adalah sebesar $35,57 \%$.

\section{Implikasi}

Dalam penelitian ini, indikator terendah dalam variabel pemanfaatan media internet sebagai sumber belajar adalah adanya fasilitas interaksi antarindividu seperti e-mail, web pendidikan, chatting, dan mailing list. Hal ini dapat terjadi karena fasilitas yang biasanya sering digunakan oleh siswa sebagaian besar hanya menggunakan web (www.google.com) untuk mencari informasi materi pembelajaran. Sehingga siswa belum menggunakan aplikasi lain untuk mencari sumber informasi yang digunakan dalam pelajaran, yang disebabkan karena kitidaktahuan siswa dalam mengaplikasikan aplikasi lain selain menggunakan web. Penggunaan e-mail sendiri hanya sebatas mengirim tugas yang diberikan guru/ sebatas guru memberikan kisi-kisi materi pembelajaran yang perlu dipelajari oleh siswa, sehingga dengan terbatas nya pemanfaatan fasilitas dalam jaringan internet ini kurang memotivasi belajar siswa dalam memperoleh sumber materi yang lebih baik dalam menunjang materi pembelajaran. Selain itu variabel motivasi belajar siswa yang terendah merupakan motivasi belajar ekstrinsik. Hal ini dapat terjadi karena motivasi belajar ekstrinsik merupakan dorongan/ rangsangan belajar yang timbul dari luar diri seorang siswa. Tujuan yang diinginkan dari tingkah laku yang digerakan oleh motivasi ekstrinsik terletak diluar tingkah laku tersebut, disini dibutuhkan penguatan yang dilakukan oleh guru pendidik dan keluarga. Guru sebagai pendidik bertugas memperkuat motivasi belajar siswa selama kegiatan belajar mengajar berlangsung, sedangkan orang tua bertugas memperkuat motivasi belajar sepanjang hayat. 


\section{Saran}

Berdasarkan kesimpulan dan implikasi yang dikemukakan di atas, saran-saran yang dapat diberikan peneliti adalah:

1. Perlunya peningkatan frekuensi dalam pemanfaatan media internet sebagai sumber belajar untuk meningkatkan motivasi belajar siswa, sehingga siswa terbiasa memanfaatan media internet dalam kegiatan belajar dikelas dan juga terbiasa dalam mengoprasikan internet (tidak gaptek).

2. Dalam motivasi belajar siswa perlu adanya keseimbangan antara motivasi belajar yang berasal dari dalam diri siswa (intrinsik) dan motivasi belajar yang berasal dari luar diri siswa (ekstrinsik), sehingga di dalam pemenuhannya memperoleh hasil yang optimal.

3. Untuk penelitian selanjutnya, diharapkan mengembangkan penelitian ini dengan cakupan populasi yang lebih luas ataupun dengan menambah variabel lain yang juga menjadi faktor yang mempengaruhi motivasi belajar siswa.Diharapkan pula melakukan variasi penelitian di Sekolah Menengah Atas (SMA) ataupun Sekolah Menengah Pertama (SMP) sehingga dapat diperoleh karakteristik siswa yang berbeda.

4. Untuk guru, diharapkan hendaknya guru memberikan penugasan-penugasan yang menuntut siswa mencari informasi melalui internet, sehingga dapat meningkatkan motivasi belajarnya.

5. Untuk siswa, diharapkan siswa yang memiliki motivasi belajar rendah dapat menyadari akan pentingnya mengarahkan diri agar lebih tangguh dalam berupaya unggul di antara individu lainnya. Akan tetapi, tetap berada pada koridor norma yang berlaku di masyarakat atau dengan kata lain, bersaing secara positif.

6. Untuk sekolah, diharapkan dapat mengontrol perkembangan motivasi belajar siswa dan sekolah dapat menyediakan laptop di setiap meja belajar siswa, sehingga siswa yang tidak memiliki laptop/ handphone dapat mengakses aplikasi internet dengan mengakses ketersediaan WIFI yang sudah dipasang disetiap kelas sehingga motivasi belajar siswa menjadi semakin meningkat. Dan juga sekolah dapat menambah kapasitas/ bandwith terhadap WIFI yang sudah disediakan agar dalam pemanfaatannya tidak terjadi kendala seperti lemotnya jaringan WIFI ketika sedang digunakan seluruh siswa.

\section{DAFTAR PUSTAKA}

A.M, Sadirman, Interaksi dan Motivasi Belajar Mengajar. Jakarta: Rajawali Pers, 2010.

Ah, Pengajaran Guru Masih Membosankan! 
KOMPAS.com.htm. Diakses pada hari selasa 9 Desember, 2014.

Ariani Niken dan Dany Haryanto. Pembelajaran Multi Media di Sekolah: Pedoman Pembelajaran Inspiratif, Konstruktif, dan Prospektif. Jakarta: PT. Prestasi Pustakaraya, 2010.

Arikunto, Suharsimi. Prosedur Penelitian Suatu Pendekatan Praktek. Jakarta: Reineka Cipta, 2006.

Arsyad Azhar, Media Pembelajaran. Jakarta: PT Raja Grafindo Persada, 2011.

B. Uno Hazah, Teori Motivasi dan Pengukurannya. Jakarta: Bumi Aksara, 2006.

Darmawan Deni. Pendidikan Teknologi Informasi dan Komunikasi. Jakarta: Rosda, 2011.

Dimyati dan Mudjiono, Belajar dan Pembelajaran. Jakarta: PT Rineka Cipta, 2006.

Djaali $\mathrm{H}$, dan Muljono Pudji, Pengukuran Dalam Bidang Pendidikan. Jakarta: Grasindo, 2008.

Djamarah Syaiful Bahridan Aswan Zain. Strategi Belajar Mengajar. Jakarta: PT Asdi Mahasatya, 2006.

Fauzi Ahmad, Hamzari Wan, and Nawawi Mokhtar. Use of Internet For Academic Purposes Among Students In Malaysian Institutions of Higher Education, Skripsi, 2014.
Hamalik, Dr. Oemar, Proses Belajar Mengajar. Jakarta: PT Bumi Aksara, 2009.

Harefa Andrias, Menjadi Manusia Pembelajar "On Becoming $A$ Learner". Jakarta: Kompas, 2000.

Hariyadi Sigit. Jurnal Penelitian: Meningkatkan Motivasi Belajar Melalui Layanan Penguasaan Konten Dukungan Tampilan Kepustakaan Berbasis TIK. ISSN 2252-6374, 2012.

http://news.detik.com/read/2012/12 /20/173457/2123806/10/didepan-wapres-boediono-siswasma-di-ternate-keluhkaninternet. Diakses pada tanggal 12 Januari 2015, pukul 08.04.

http://www.republika.co.id/berita/ko ran/pendidikankoran/14/08/22/naoz886menghadapi-tantangankurikulum-2013. Diakses pada hari senin, 8 Desember, 2014.

Imron Ahmad Ali .Pengaruh Pemanfaatan Internet Terhadap Motivasi Belajar Mahasiswa (Studi pada Program Studi Pendidikan Ekonomi STKIP PGRI Jombang), Skripsi, 2013.

Iskandar. Psikologi Pendidikan Sebuah Orientasi Baru. Jakarta: Gaung Persada Press Group, 2012.

Jamil. Pengaruh Penggunaan Internet Sebagai Sumber Belajar Terhadap Motivasi Belajar Mata Pelajaran Ekonomi di SMA, Skripsi, 2014. 
Kustandi Cecep, Sutjipto Bambang, Media Pembelajaran Manual dan Digital. Bogor: Ghalia Indonesia, Februari 2011.

Marisa, dkk. Komputer dan Media Pembelajaran. Tanggerang: Universitas Terbuka, 2012.

MiarsoYusufhadi. Satuan Tugas dan Definisi Terminologi AECT Definisi Teknologi Pembelajaran. Jakarta: Raja Grafindo Persada, 2010.

Musfiqon.Pengembangan Media dan Sumber Pembelajaran. Jakarta: PT. Prestasi Pustakaraya, 2012.

Oetomo, Budi Sutedjo Dharma Oetomo. E-education Konsep, Teknologi dan Aplikasi Internet Pendidikan. Yogyakarta: Andi, 2007.

Sadirman Arief. Media Pendidikan: Pengertian, Pengembangan, dan Pemanfaatannya. Jakarta: Raja Grafindo Persada, 2008.

Slameto, Belajar dan Faktor-faktor yang Mempengaruhi. Jakarta: Rineka Cipta, 2010.
Soemarno Utari dan Abdulhak, $\mathrm{H}$. Ishak, Pendidikan Tekonologi Informasi dan Komunikasi. Jakarta: Rosda, 2011.

Sugiyono, Metode Penelitian Kuantitatif, Kualitatif dan R\&D. Bandung: Alfabeta, 2011.

Sugiyono. Statistika Untuk Penelitian. Bandung: Alfabeta, 2012.

Sukiman. Pengembangan Media Pembelajaran. Yogyakarta: PT. Pustaka Insan Madani, 2012.

Sultoni Ahmad, Pengaruh Pemanfaatan Internet Sebagai Sumber Belajar Sejarah Terhadap Motivasi Belajar Siswa Kelas XI IPS SMAN 1 Wiradesa Kabupaten Pekalongan Tahun Pelajaran 2011/2012. Universitas Negeri, Skripsi, Semarang : 2013.

Syukur Fatha, NC, Teknologi Pendidikan. Semarang: RaSAIL Media Group, 2008.

Warsita Bambang, Teknologi Pembelajaran. Jakarta: Rineka Cipta, 2008. 